\title{
Institutional Dynamics and Economic Development in Greece: An Acemoglian Approach
}

\author{
Charis Vlados ${ }^{1,2} \&$ Dimos Chatzinikolaou ${ }^{1, *}$ \\ ${ }^{1}$ Department of Economics, Democritus University of Thrace, PO Box 69100, \\ Panepistimioupoli, Komotini, Greece \\ ${ }^{2}$ School of Business, University of Nicosia, PO Box 24005, CY-1700, 46 Makedonitissas \\ Avenue, CY-2417, Nicosia, Cyprus \\ *Correspondence: Department of Economics, Democritus University of Thrace, PO Box 69100, \\ Panepistimioupoli, Komotini, Greece. Tel: 30-25310-39824 E-mail: dimchatz@econ.duth.gr
}

Received: January 29, 2020 Accepted: February 26, 2020 Published: March 6, 2020

doi: 10.5296/rae.v12i1.16631 URL: https://doi.org/10.5296/rae.v12i1.16631

\begin{abstract}
The evolution of institutions is a theoretical field of increasing interest today. Socio-economic development in the institutional approach results mainly from the historical unfolding and quality of institutions. This paper aims to highlight Daron Acemoglu's institutional approach, which appears to be gaining prominence gradually, and propose a new theoretical perception of the developmental process of the Greek socio-economic system. It first analyses Acemoglu's theoretical contribution, it then compares the 'Acemoglian' to other approaches and suggests that the analysis of inclusive and extractive institutions based on historically-significant virtuous and vicious circles has value for the Greek case. While several studies tend to focus on the macroeconomic and macro-financial symptoms of the Greek crisis, an evolutionary approach of the deeper institutional dynamics seems to offer a required reposition. We describe and recommend the development and underdevelopment process in terms of an 'institutionally adaptive socio-economic system' and 'competitiveness web'. These findings indicate that development takes place over historically-significant periods, through complex processes of selection and diffusion of institutional restructurings, and that civil societies are responsible for the political forces who represent them, at least in democratic regimes. In the case of Greece, the proposal to utilise an approach of an 'institutionally adaptive socio-economic system' can give a repositioned theoretical perception, especially nowadays when the institutional and evolutionary socio-economic analytical classes seem to be gaining interest and prominence.
\end{abstract}

Keywords: Daron Acemoglu, Greek crisis, why nations fail, socio-economic development, institutionally adaptive socio-economic system, institutional innovations, competitiveness web 


\section{Introduction}

The Greek crisis constitutes a point of reference and case study for the unsuccessful adaptation of a developed country into the current restructuring dynamics and crisis of globalisation (Bodenstein et al., 2017; Vlados et al., 2019).

A presentation of Greece's macroeconomic data over the last years illustrates perhaps one of the most complex and time-consuming structural adjustments of a developed economy in modern history. In 2004-2007, the unemployment rate was 9.5\% while in 2013-2015 rose at $26.3 \%$, and the forecast for 2020 is at $16.9 \%$. According to the latest European Semester report for Greece (European Commission, 2019), the general government balance was -6.9\% of GDP between 2004 and 2007 and $-11.1 \%$ for 2008-2012, while forecasts estimate a positive balance of $0.6 \%$ for 2020 . At the same time, Greece recorded at the end of 2018 the highest debt to GDP ratio in the EU at 180\%, whereas before the beginning of the crisis, between 2004 and 2007, this ratio was already high at $104.2 \%$ (Figure 1).

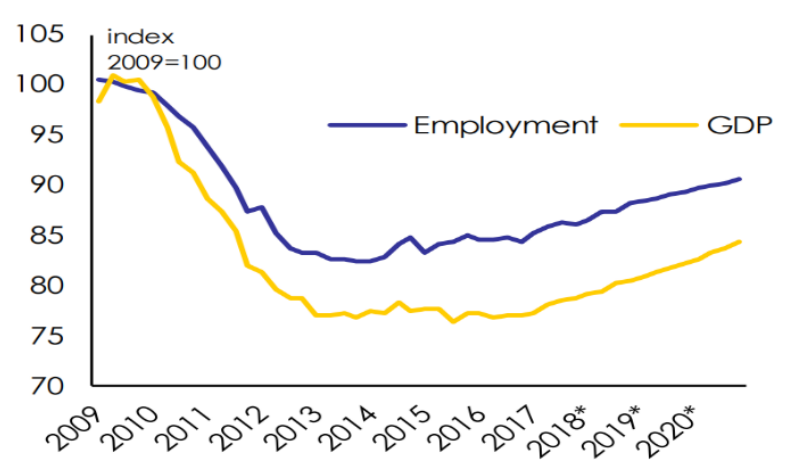

Figure 1. Employment and GDP Dynamics in Greece (European Commission, 2019)

The European Commission officials note further in this report that reducing imbalances accumulated during the pre-crisis years will require the sustained implementation of profound structural and institutional reforms (Leitch, 2019) since Greece has been undertaking such reforms to modernise the state and the economy recently, although a prolonged period of sustained growth is still necessary. The report also shows the contribution of domestic demand in GDP growth at $4.6 \%$ in 2004-2007 and the respective contribution of net exports at $-0.8 \%$ while the forecast for 2020 is the contribution of domestic demand to reach $1.6 \%$ and net exports to $-0.1 \%$. This imbalance and the large gap between demand and supply (and in particular, advanced supply deriving from exports) reveal structural problems of competitiveness and weak institutions, well before the onset of the crisis.

One of the leading proponents of studying these structural development deficiencies at an international level and from an institutional perspective is Daron Acemoglu. Acemoglu also dealt with the subject of the Greek crisis through relevant interviews in the Greek media (Psichari, 2012). Amidst the severe manifestations of the crisis, Acemoglu acknowledged that 
the Greek people have to, first, get rid of the 'corrupt politicians' who are responsible for this situation and accept that they will live with inferior standards. Acemoglu noted the 'poor quality of leaders' in Greece and the fact that Greek and European institutions tend to back these corrupt elites. He also noted that it would be a mistake to blame the EU for Greece's problems since in Greece people do not work as much and evade taxes, not because of the 'inherited' values or some national predisposition, but because of the incentives that Greeks created. He explained that politicians created a system that does not reward hard work, people can evade taxes easily, and clientelism has made entrepreneurship and innovation less attractive.

Acemoglu also declared that the prospects for Greece are not promising unless it undergoes radical reforms in its 'corrupt political system', the market, the labour market, and the public sector, while on the external debt front, very few things were done and very slowly. He suggested that debt restructuring should have been more comprehensive and done in 2010 instead of 2012, although this thing did not happen because politically powerful French and German banks prevented it (Papadopoulos, 2014). Nevertheless, he insisted that Greece is not without responsibility since Greek people lived before the crisis beyond their available means and, indeed, the 'corrupt political order' is responsible, but the people agreed. Therefore, his proposal for the country was to set a different course by improving, through substantial radical and political reforms, the areas of work motivation, investment, and innovation that can contribute to a much higher standard of living.

Following these introductory remarks, it seems useful to delve deeper into the extent to which Acemoglu's work and theoretical contribution have further implications on the Greek crisis debate. That is, to explore the connection between Acemoglu's observations on the Greek crisis with his various institutional research contributions and find out the constituents of his work on contemporary economics of development. The aim is to see if we can exploit the 'Acemoglian approach' in the effort of suggesting a sustainable way out of the crisis by constructing a new development model.

\section{Methodology}

The final goal of the paper is after presenting the main analytical axes of Acemoglu's work to recognise the fundamentals for a new institutional and evolutionary comprehension of the Greek crisis. The subsequent analysis of the paper includes the following steps of examination in order of appearance:

1. The initial section presents and discusses essential elements of Acemoglu's theoretical work on the dynamics of development and institutions, distinguished in four categories:

i. First, it presents the focal points of Acemoglu's approach to the issue of general socioeconomic development.

ii. Second, it focuses on those works analysing the main components of institutional development dynamics.

iii. Then, it analyses the main findings of the book 'Why nations fail: The origins of power, 
prosperity, and poverty', a work translated in many different languages that gave Acemoglu a worldwide prestige and reputation.

iv. Fourth, it distinguishes and presents the main analytical ingredients and reasoning of the 'Acemoglian' approach.

2. Subsequently, it presents an indicative sample of studies on the case of the Greek crisis by focusing on those discussing and analysing institutional elements. It concludes by presenting a new analytical scheme to deepen the study of institutional dynamics in unified terms for the different socio-economic systems.

3. The final section evaluates the conducted study by discussing the central relationships between the work of Acemoglu with the different socio-economic and political approaches to the Greek crisis. It identifies mutual fertile points that can deepen the research, and suggests future directions.

\section{Institutions and the Dynamics of Development in Acemoglu's Work}

According to Acemoglu (2012, p. 545), while economic growth is 'one of the most relevant and exciting sub-areas of economics [the] problem of economic development remains a major one for humanity at large and for economics as a science'. The author makes a clear distinction between economic growth and development (Perroux, 1969), arguing for the central importance of historically shaped institutions in societies. In the work of Acemoglu, we come across historical reports and analyses starting from highlighting significant socio-economic changes and transitions, such as the Industrial Revolution of the nineteenth century, as well as technological discoveries that appear to have changed (and still changing) the content of the surrounding institutions in trans-disciplinary terms.

The following brief overview of Acemoglu's theoretical work describes the author's central analytical points, argumentation, and conclusions. It attempts to distinguish in the end the main points of what we could call as the 'Acemoglian approach'.

Table 1 presents the main features of the author's perspective on the issues of general socioeconomic development and policy by presenting a summary of relevant studies in chronological order. 
Table 1. The Process of Development and Economic Policy in Acemoglu's Literature

\begin{tabular}{|c|c|}
\hline Authored by & Focal points \\
\hline $\begin{array}{l}\text { Acemoglu and } \\
\text { Robinson (2001) }\end{array}$ & $\begin{array}{l}\text { 'Asset redistributions' is the factor that } \\
\text { defines the political stability or instability of } \\
\text { both democratic and non-democratic } \\
\text { regimes. }\end{array}$ \\
\hline Acemoglu (2010b) & $\begin{array}{l}\text { Economic, social, and political development } \\
\text { is more significant than the narrow focus to a } \\
\text { specific set of factors conducted in most } \\
\text { economic analyses. }\end{array}$ \\
\hline $\begin{array}{l}\text { Acemoglu et al. } \\
(2010)\end{array}$ & $\begin{array}{l}\text { Analyse historical correlations such as GDP } \\
\text { per capita and lower average wages at } \\
\text { administrative districts that experienced the } \\
\text { Holocaust. }\end{array}$ \\
\hline
\end{tabular}

Acemoglu et al.

Acemoglu and

Robinson (2013)

Acemoglu et al.

Acemoglu et al. (2019)
What feeds populist politics is the failure of democratic institutions.

The 'standard' approach to policy-making in economics that assumes that market failures should be removed rapidly is no longer efficient.

Analyse political economy problems from a stochastic perspective, which allows for predicted and unexpected shocks that can change political power distribution.

To prove the positive and consistent effect of democracy on GDP per capita.
The impact of the Holocaust on the social structure (such as, on the size of the white-collar class) across various regions of Russia may be partly responsible for adverse long-run economic and political effects.

Unequal societies are less likely to improve democracy and can inevitably swing between different regimes and suffer significant fiscal instability.

Development economics ought to include general equilibrium and political economy effects. For example, specific economic policies tend to have more significant, complex, and multiform effects than what the "pure" economic analysis would suggest.

Populist policies arise as a way for politicians to show that they will implement alternative policies that are in line with the desires of the median voter.

The political economy must be thoroughly analysed as the basis for sound economic policies that take into consideration its impact on future political balances.

The suggested framework can go beyond the political economy and include organisational (such as the firm's internal politics) and international relations issues.

Democracy facilitates economic growth, while various complementarities exist between democratic institutions and proximate causes for economic development. 


\section{Macrothink}

Research in Applied Economics

ISSN 1948-5433

2020, Vol. 12, No. 1

In terms of the development process, the central axes of the 'Acemoglian' approach appear to be the following:

a. Development differs from growth, as the political choices of a society affect many more factors than those assumed by the 'real' economic analysis, which focuses on the immediate removal of market failures.

b. Examination of economic data (such as GDP per capita) can lead to conclusions about the development process of an area (a nation) when considering their unfolding in historical terms.

c. The political economy of development is fundamentally a stochastic process as there are unpredictable events that change the course of history.

d. The regime of democracy ultimately enhances economic growth. Weak democratic institutions favour populist politicians and lead to long-term development hysteresis and blockages.

Acemoglu's approach also has an explicit institutional character, analysed from a historical perspective. Table 2 presents relevant works by the author that focus primarily on institutional issues.

Concerning the institutional components of economic development, the 'Acemoglian' approach seems to have the following characteristics:

- Comparative institutional dynamics rather than geography, or a particular culture, or religion predeterminations, seem to play the most decisive developmental factor in societies.

- The study of the institutional context of development is a historical analysis primarily.

- Institutions are the principal cause of long-term growth.

- Standard neoclassical models cannot explain the structure and historical transition of general social and political power.

- After all, the modern world is interdependent, and growth is structurally asymmetric for all the participant socio-economic entities.

- The global development 'equilibrium' means that institutions vary between different socioeconomic systems in the sense that their transfer from one nation to another cannot happen 'immediately'. 
Table 2. Institutional Components of Economic Development in Acemoglu's Literature

\begin{tabular}{|c|c|}
\hline Authored by & Focal points \\
\hline $\begin{array}{l}\text { Acemoglu et al. } \\
(2001)\end{array}$ & $\begin{array}{l}\text { Europeans established or maintained existing } \\
\text { extractive institutions in prosperous and densely } \\
\text { settled areas, while they encouraged trade and } \\
\text { industry by settling and creating private } \\
\text { property institutions in previously sparsely } \\
\text { settled areas. }\end{array}$ \\
\hline $\begin{array}{l}\text { Acemoglu et al. } \\
(2002)\end{array}$ & $\begin{array}{l}\text { The rise of Europe resulted from the bourgeoisie } \\
\text { in Western Europe, which generated significant } \\
\text { profits from Atlantic trade and managed to } \\
\text { demand, obtain, and sustain institutional } \\
\text { reforms that protected capitalist property rights. }\end{array}$ \\
\hline $\begin{array}{l}\text { Acemoglu and } \\
\text { Johnson (2003) }\end{array}$ & $\begin{array}{l}\text { Institutions are of primary importance to } \\
\text { financial and economic performance, such as } \\
\text { 'contracting institutions' that allow private } \\
\text { contracts between citizens and 'property rights } \\
\text { institutions', which protect citizens' property } \\
\text { rights from rulers. }\end{array}$ \\
\hline
\end{tabular}

Acemoglu et al. (2004)

Acemoglu (2010a)

Acemoglu et al. (2012)
To propose an institutional framework that explains why some countries grow and develop faster than others.

Many of the disastrous economic institutions and policies create obstacles to entry or indirectly manipulate factor prices to transfer resources from entrepreneurs and workers in political groups and guild interests.

There is an 'asymmetric world equilibrium' in which some nations choose a sort of 'cutthroat capitalism' that produces greater inequality and more innovation, while others 'free-ride' on the cutthroat incentives of the leaders and choose a more 'cuddly' form of capitalism, which is poorer but may result in increased welfare.
Institutions, not geography, have driven the growth and shaped cross-country disparities in economic outcomes in areas colonised by European powers over the past 500 years.

Thus, pre-1500 trends in Europe, such as religion and Roman heritage, are not as significant.

Findings in European colonies show that property rights institutions have a significant impact on long-term economic growth, investment, and financial development, while contracting institutions affect the forms of financial intermediation primarily.

Politics, the structure of political power, and the nature of political institutions are the basis for a valid theory of why different countries have different economic institutions and not the neoclassical growth model and its extensions.

State capacity with sufficient economic strength is essential for economic development through taxation, regulation, and delivery of public goods, although an 'autonomous' increase in the strength can rise the controlling power of the state.

We cannot all be like the Scandinavians in this equilibrium since Scandinavian capitalism relies, in part, on the 'spill-overs' created by the 'cutthroat' American capitalism. 
Moreover, the best-selling book 'Why nations fail: The origins of power, prosperity, and poverty' we can say is a compilation effort of the works presented above and describes eloquently and thoroughly the 'Acemoglian' approach. According to Acemoglu and Robinson (2012, p. 45), the 'focus of our book is on explaining world inequality and also some of the easily visible broad patterns that nest within it'. Some of the highlights of the book are the following:

- We need a theory of both economics and politics to study the effects of institutions on the success and failure of nations; the 'economics of poverty and prosperity'.

- The same mechanism that fuelled European growth (commercial and colonial expansion) imposed or, at the very least, reinforced extractive institutions that underpinned the poverty of specific nations. This is a paradox of 'reversed development' that can explain world inequality.

- The usurping of power is much more difficult in pluralistic political institutions as these enshrine the rule of law that increases political participation, eliminates the most extreme extractive economic relations, such as slavery and serfdom, diminishes the influence of monopolies, and makes free media thrive.

- The elites sustain their wealth and dominance through extractive institutions, which place little restrictions on the exercise of power and, thus, leave no space for institutions that can restrain the abuse of power by those who take control. A potential change towards inclusive institutions can be the mobilisation of a broad coalition that can challenge absolutism and replace absolutist institutions with more democratic and pluralistic ones.

- There is no 'iron law of oligarchy' since pre-existing inclusive elements in institutions or the formation of coalitions that can challenge the existing regime (or the 'contingent nature of history') can break vicious circles.

Overall, for the factors that ultimately make nations differ from one another in terms of institutions, the 'Acemoglian' approach suggests centrally that national prosperity or poverty depend on the existence of 'inclusive' or 'extractive' institutions by virtuous or vicious circles, respectively. This approach realises that global inequality depends on the particular history that incubates political, economic, and social relations through conflicting and, primarily, evolutionary processes. Inclusive economic institutions favour private property rights, encourage investment in new technologies and skills, and distribute power pluralistically while extractive economic institutions extract resources from the poor, provide fewer development incentives, and tend to concentrate the means of power.

Figure 2 illustrates these evolutionary/institutional progressions that drive national prosperity or national poverty by also placing into the theory the sphere of global development and the parallel adjustment and changing of hierarchies, which offers a converging interpretation to the 'contingent path of history' that Acemoglu uses to highlight the complexity of institutional creation. 


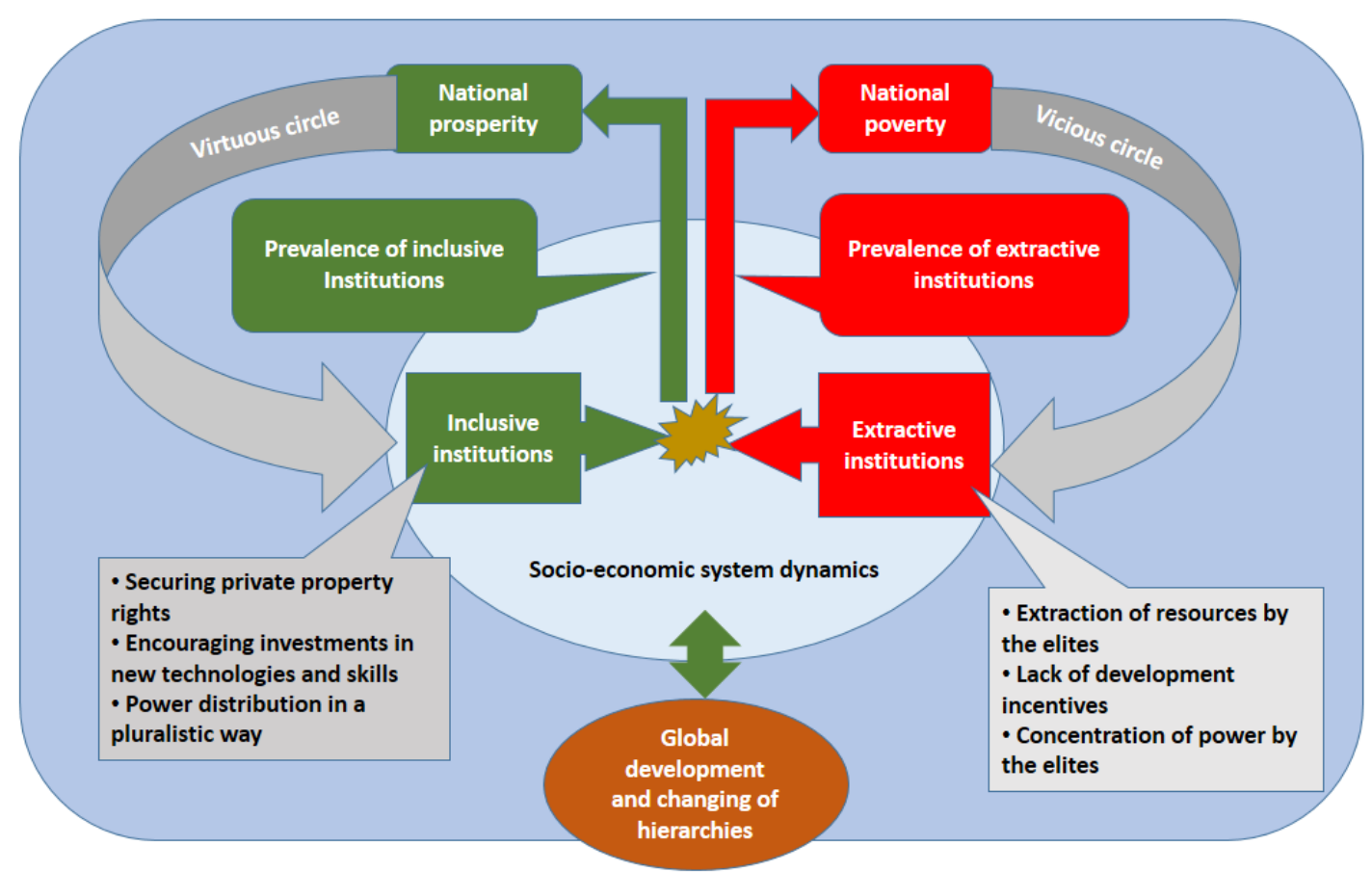

Figure 2. National Prosperity or Poverty in the 'Acemoglian' Approach, Based on Vlados and Chatzinikolaou (2019)

\section{Approaches to the Greek Crisis: Searching for a Theoretical Counterproposal to an 'Institutionally Adaptive Socio-economic' System Analysis}

How has the academic community approached the problem of the Greek crisis, and what institutional barriers does it recognise? This section presents relevant to the Greek crisis analyses and their main features.

One critical dimension of the crisis is that it always constitutes a radical readjustment of the existing situation in a 'structural' way (Andrikopoulos \& Nastopoulos, 2015; Vlados et al., 2018), that is, structural crisis means a change to the existing balance in the deeper qualitative and quantitative features of the current status quo. In simple words, after a crisis is over, things never go back to their previous state.

Many scholars have been trying recently to interpret the issue of the specific Greek structural crisis from complementary perspectives. As Kentikelenis (2018) argues, Greece followed a 'debt-led expansion model' after entering Eurozone to finance excessive government consumption instead of public investment in areas that could boost public revenues. Mitsakis (2014) explains the Greek crisis as a partial crisis of the European financial system resulted from the global economic recession that initiated in 2007; subsequently, the Greek economic crisis turned into a general socio-political crisis.

Christodoulakis (2010) attributes the Greek crisis to the yearly increase of public debt from the country's accession to the European Monetary Union (EMU) until 2007. In a similar 'financial crisis' orientation, Kuforiji (2016) and Tsoulfidis et al. (2016) consider this crisis as a symptom 
faced by most of the peripheral Eurozone countries, while Kazemi and Sohrabji (2012) analyse the total 'sovereign debt crisis contagion' in 'PIIGS' countries (Portugal, Ireland, Italy, Greece, and Spain).

Magoulios and Chouliaras (2014) note the role of decreased private and public consumption and investment to Greece's GDP decline within the crisis. Hardouvelis and Gkionis (2016) start their analysis of the Greek crisis from the fiscal deficits that were growing larger since 2006. Zettelmeyer et al. (2013), and Kouretas and Vlamis (2010), note that the Greek debt crisis started in October-November 2009 when the Greek government acknowledged that their budget deficit and public debt were not sustainable. Christopoulou and Monastiriotis (2016), although identifying the impact of the Greek crisis primarily on the public sector, they also discuss the influence of the crisis on the private sector.

Bitzenis et al. (2016) explore how the 'Greek shadow economy', such as tax evasion, undeclared work, and corruption, contributed to the crisis. Ioannides and Pissarides (2015) suggest that 'supply' problems in Greece are present since entering the European Union in 1981, while austerity and wage cuts that caused 'demand' problems worsened even further in this situation. Triantopoulos and Staikouras (2017) investigate the inefficiency of Greek 'stateowned enterprises' that fuelled the worsening of public finances; the authors blame the reluctance of policymakers to implement structural reforms.

Moreover, Koniordos (2011) explores the implications of the Greek citizens realising progressively in the crisis that they can no longer 'live on borrowed money'. Finally, Juko (2010) and Glynos and Voutyras (2016) identify problems related to mass media's disorientating influence in Greece that worsened the overall political environment.

Therefore, a plethora of scholars on the problem of the Greek crisis focuses on partial problems, mainly of 'macroeconomic' and 'macro-financial' origin.

i. Most analyses highlight the problematic handling of financials by the Greek government that led to the crisis.

ii. At the same time, they focus on the 'coincidence' of Greece's location at the European South hit by the symptoms of the generalised European sovereign debt crisis.

iii. Finally, the 'debt crisis' in Greece, for most analysts, manifests mostly in the public sphere; it is a problem of 'Keynesian effective demand' (Stockhammer, 2017).

\subsection{The Institutional Problematics of the Greek Crisis}

Although these approaches to the Greek crisis are quite comprehensive and provide a solid analytical background, the institutional dimension of the problem seems to be relatively underutilised. The problem of the Greek crisis is undoubtedly multi-dimensional, institutional, and structural, and there are relative analyses that discuss such implications.

According to Andreou et al. (2017), the sovereign debt crisis dynamics in Greece are due to the institutional weaknesses of the Greek economy and the institutional design of the Eurozone while Mitsopoulos and Pelagidis (2018) highlight the need to speed up the institutional 
convergence' between the EU member states. Pelagidis and Mitsopoulos (2016) also contend that austerity and populism are the significant forces undermining the already weak institutional setting in Greece. Skalkos (2018) considers the catalytic role of specific organised interest groups in Greece that help to sustain clientelistic relations. Koutsoukis and Roukanas (2011) deal with the Greek crisis not only from the macroeconomic perspective but also from the lack of real political development.

Mavroudeas (2016) declares the problem of the Greek crisis as structural instead of 'conjunctural', caused by the tendency of the rate of profit to fall due to the increase of the organic composition of capital. However, according to Vlados (2019), this 'neo-Marxist orientation', although it enlightens critical aspects of the actual global capitalist restructuring, is misleading since it omits the contemporary forces of entrepreneurial innovation, general industrial mutation, and socio-economic competitiveness challenges deriving from the inherent 'creative destruction' on a global scale.

Theocharis and Deth (2015) explore the institutional causes of the Greek crisis, which are social and political instead of economic or financial. They point to specific 'civic pathogenies' of the Greek society by documenting how the country ranks last in Europe in trust, confidence, and political corruption indicators. Pappas (2013) explains why Greece developed a populist regime that managed to sustain for decades a system that exploited the resources of the state; Greece is an example to avoid for developed Western democracies. Sumer (2015) traces the roots of the Greek crisis in the external and internal institutional and political conditions by noting the actions of Greek politicians that favoured rent-seeking interest groups and ignored the economy's long-term sustainability. These actions turned the country vulnerable to the crisis in economic and financial terms.

Siskos and Marangos (2017) acknowledge accounting education as critical for recognising the causes of the recent Greek financial crisis and preventing future similar failures. They suggest changes in the accounting curriculum in tertiary education in Greece. To this end, we would note that an integrated and 'cross-sectoral' understanding of the required changes in education would be useful. In today's globalised sectors of economic activity, clusters, and business ecosystems of innovation, national competitiveness includes multi-level and cross-sectoral elements (Vlados \& Chatzinikolaou, 2019a).

In the institutional approach by Pitelis (2012), the competitiveness model of Greece laid the ground for the subsequent collapse. According to Pitelis, Greeks have to blame mostly themselves for becoming the weak link of a chain, although he also notices a lack of leadership in the EU followed by neoliberal economic policies of myopic nature. At this point of criticism of 'neo-liberalism', we would suggest particular attention. According to Vlados (2006), often enough, scholars and policymakers baptise as 'neo-liberalism' heterogeneous mixtures of economic policy that are 'idiosyncratic' compositions of conservative, neo-interventionist, and supposedly pragmatic constituents and parts of nation-centred priorities, which have little to do with the original meaning of liberalism.

In conclusion, several analyses seem able to provide a more comprehensive framework for interpreting the Greek crisis, mainly from an institutional perspective. 


\section{Macrothink Institute ${ }^{\mathrm{TM}}$}

i. The institutional weakness of the Greek socio-economic system involves structural features, expressed as 'pathogenies' at the level of civil society mostly.

ii. Democracy in Greece also seems to be facing problems of relative underdevelopment and 'retreat' as the forces of populism and clientelism gain power.

iii. Greece belongs to the developed western democracies, but the 'wrong choices' of society can lead to institutional weakening and backwardness.

\subsection{Towards a New Evolutionary Approach of the Greek Socio-economic Crisis and Restructuring}

According to Vlados and Chatzinikolaou (2019), an evolutionary perspective can offer a more comprehensive approach to the Greek crisis. They present a proposal for a sustainable exit of the Greek crisis based on the creation and maintenance of an 'institutionally adaptive socioeconomic system' that depends primarily on structural reforms and institutional innovations (Figure 3).

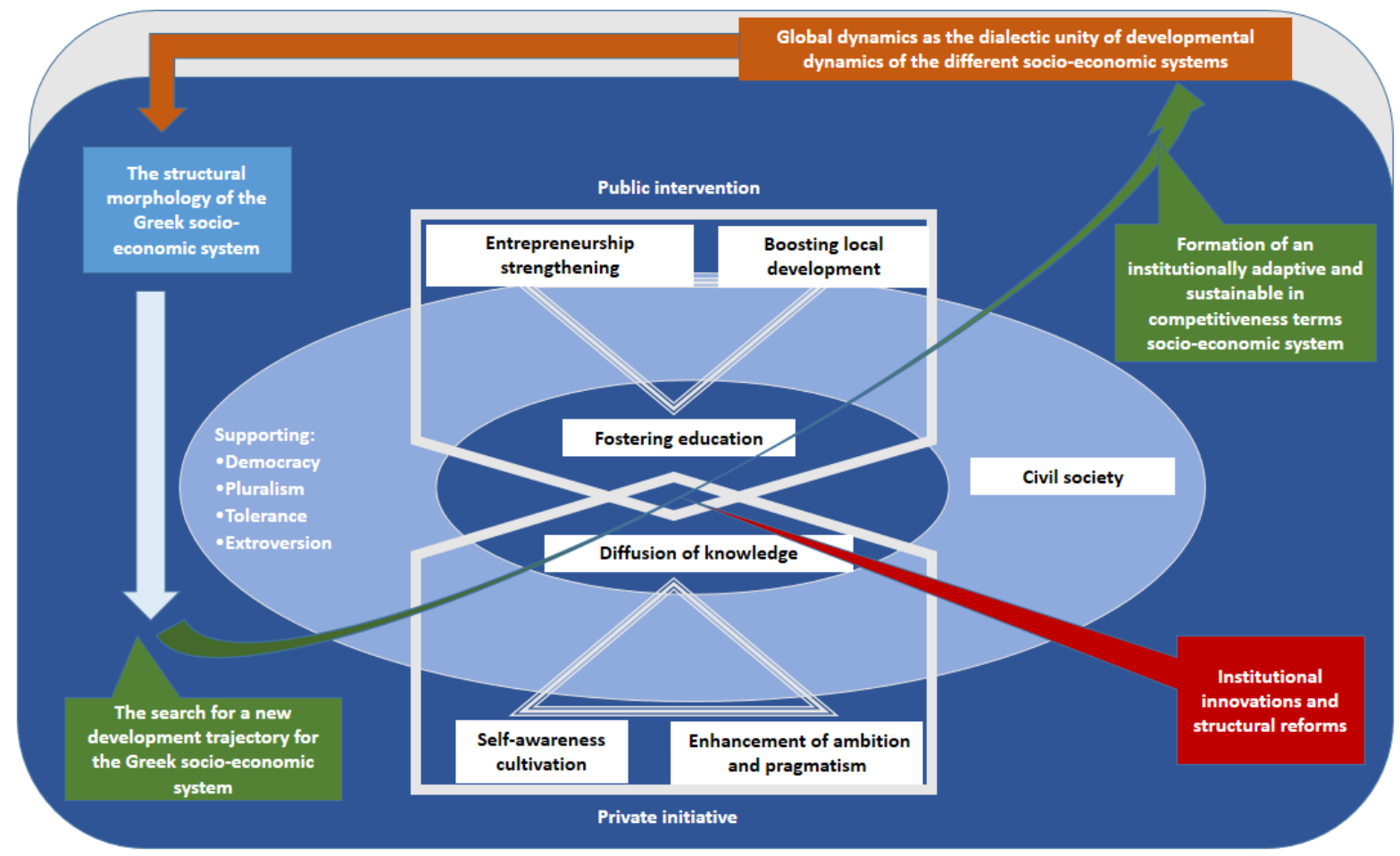

Figure 3. An 'Institutionally Adaptive Socio-economic System', Based on Vlados and Chatzinikolaou (2019)

Institutional innovations are those changes that gain legitimacy over time, and that can change the cognitive, normative, and regulatory environment of a socio-economic system through structural reforms (Raffaelli \& Glynn, 2015). An 'institutionally adaptive socio-economic system' intersects two significant forces: public intervention and private initiative. Public intervention should target free-access education, entrepreneurship strengthening, and boosting 


\section{Al Macrothink Institute ${ }^{\mathrm{TM}}$}

local development. The private initiative should focus on the diffusion of knowledge, cultivation of self-awareness, and development of ambition and pragmatism. Civil society affects these forces simultaneously by the way it supports democratic institutions, pluralism, tolerance, and extroversion.

An institutionally adaptive socio-economic system also interacts with dynamic and competitive processes with other socio-economic systems by creating, thus, the dynamics of global development. The dialectics of the global developmental process crosses and transforms the structural morphology of the Greek socio-economic system, which deals with a crisis of structural reshaping and has to adapt in institutional terms and schematise a new evolutionary trajectory (Nelson et al., 2018) of development in global dynamics.

According to Vlados (2019a), this new evolutionary path depends on the overall competitiveness of the socio-economic system, which is the result of complex relationships in the form of a 'competitiveness web' that illustrates the interactions and interdependence between the different structured environments (Figure 4).



Figure 4. The Institutional Framework of Development and the Competitiveness Web, Based on Vlados (2019a)

The Greek socio-economic system, under the 'competitiveness web' perspective, must improve primarily the way it competes within the global dynamics. The competitiveness web presents the different structured environments of the socio-economic system by acknowledging first the central role of the dynamics of the firms. It then posits the overarching meso-economic 'Porterian' dynamics of industries, where clusters of firms in specific national industries compete based on the four determinants of firm strategy, structure, and rivalry, factor conditions, demand conditions, and related and supporting industries (Porter, 1990). The competitiveness web approach also combines the sub-system of the micro-level of the firm and the subsystem 
of the meso-level of industries with the overarching super-systems of technological and cognitive dynamics, cultural dynamics, and demographic and environmental dynamics. In this sense, the competitiveness of a socio-economic system depends and extends on multilevel creations and configurations (Peneder, 2017).

The competitiveness web also designates and adds together the interrelated spheres of overall entrepreneurial dynamics, overall institutional dynamics, and overall political (legal and regulatory) dynamics, which rearrange over time all subsystems. At the same time, it suggests the existence of an evolutionary socio-economic equilibrium that causes the socio-economic system to increase in investment performance and attractiveness in broad terms. This equilibrium depends on the ability of a socio-economic system to employ a systematic effort of institutional modernisation, to foster inclusive institutions, and to boost socio-economic competitiveness.

All these suggested schematic representations of the competitiveness web have a political orientation. Their analysis aims to stress a need of perceiving the socio-economic systems from a 'totalising' and evolutionary perspective that can allow the 'private initiative' and 'public intervention' to understand their environment as an unbreakable and, at the same time, structured system. On the one side, Acemoglu's approach to the context and evolution of institutions is undoubtedly critical since it proves the historical and political process behind the creation of inclusive institutions. On the other side, the approach of the 'institutionally adaptive system' and the 'competitiveness web' are mostly political suggestions of evolutionary character to understand the factors contributing in socio-economic development by placing at the centre the dynamics of innovation at an institutional level and the dynamics of structured subsystems, respectively. To this end, it seems that they can enrich the 'Acemoglian' approach by suggesting an overall model of developments and adaptations of the socio-economic systems into global dynamics, which also seems essential for the case of the Greek socioeconomic system.

\section{Final Remarks}

This article attempted first to present Acemoglu's thinking on the problem of the Greek crisis and then to highlight the main theoretical points of his work on the development and underdevelopment of institutions. To this end, it presented recent studies addressing the issue of the Greek crisis, distinguishing between those with an institutional perspective and those focusing on partial issues, resulting in a theoretical scheme of an 'institutionally adaptive socioeconomic system', which places institutional innovation and structural reforms at the centre.

The presented institutional analyses seem to follow the 'Acemoglian' perspective of the differences between economic growth and development and the stochastic nature of the development process, although they do not seem to give a similar emphasis as Acemoglu does on the study of history on building inclusive institutions. Acemoglu's perspective on the factors that make a nation poor or prosperous based on the historical existence of inclusive or extractive institutions helps to understand the structural problems emerging in Greece. In the 
institutional approach, which is mainly an 'evolutionary' approach (Hodgson \& Lamberg, 2018), the study of the issue of development begins primarily with the action of individuals; mostly 'civil society' in the Institutionalist approach and 'the firm' in the 'evolutionary approach of the firm' (Chatzinikolaou \& Vlados, 2019).

Undoubtedly, Acemoglu's work on the study of institutions in the socio-economic sciences is unique and vital. As evolutionary economists, we appreciate that the most significant contribution of our science is indeed to study the way societies develop while offering solutions to the fight against poverty. Economics is the 'medicine of poverty' and is continuously trying to offer solutions in battling with 'perennial scarcity'. If we could add something to the 'Acemoglian' approach, this would be a greater emphasis on the dynamics of the firm's innovation in the modern world of globalisation. For the Greek case, we appreciate that one of the critical points for the path of future development lies in building an institutionally adaptive socio-economic system along with the development of civil society. That is, in improving the overall competitiveness based on the notion of 'competitiveness web' where all the subsystems of the socio-economic system interact dynamically.

At the same time, this study has some limitations to mention. Initially, the drawing of general conclusions in the review of Acemoglu's work took into account a sample of scientific publications without taking into account the whole of his work. However, we believe that the conclusions about the main analytical points of the 'Acemoglian' approach were sufficient to identify the institutional characteristics and main analytical points and to provide a useful reposition of the studies on the Greek crisis. Another methodological limitation is the somewhat indicative presentation of analyses to the Greek crisis, although it seems that the majority of these approaches do not have an institutional perspective and direction in 'Acemoglian' terms. At the same time, fewer and more 'heterodox' approaches are those that discuss besides macroeconomic and financial problems, civil society development implications and prospects, and the quality of institutions.

Overall, this research effort did not intend to offer another macroeconomic interpretation of the Greek crisis. The main goal was to highlight the analytical utility of Daron Acemoglu's institutional approach by focusing on the case of development and underdevelopment of the Greek socio-economic system. The presentation of the 'Acemoglian' concepts of inclusive and extractive institutions through historically significant virtuous and vicious circles, as well as the central analysis of an institutionally adaptive socio-economic system, highlight the dimension of political selection and choice that civil societies undertake. In this sense, this article was an attempt to prove through successive arguments the significance of institutions and suggest finally that socio-economic development is primarily a process of political dialectics influenced continuously by the dynamics of socioeconomic 'trajectories' and evolution - as Acemoglu would suggest, there is no 'iron law of oligarchy'. Therefore, for overcoming the Greek crisis definitively, civil society should 'mature' and provide support in a gradual structuration of a more institutionally adaptive socio-economic system, which will focus on building inclusive institutions and institutional innovation, in broad terms. 


\section{Acknowledgement}

We would like to express our gratitude to Dr Andreas Andrikopoulos, Associate Professor at the Department of Business Administration of the University of the Aegean, who provided useful comments during the writing of this manuscript.

\section{References}

Acemoglu, D. (2010a). Institutions, factor prices and taxation: Virtues of strong states? (Working Paper No. 15693). National Bureau of Economic Research. https://doi.org/10.3386/w15693

Acemoglu, D. (2010b). Theory, general equilibrium, and political economy in development economics. Journal of Economic Perspectives, 24(3), 17-32. https://doi.org/10.1257/jep.24.3.17

Acemoglu, D. (2012). Introduction to economic growth. Journal of Economic Theory, 147(2), 545-550. https://doi.org/10.1016/j.jet.2012.01.023

Acemoglu, D., Egorov, G., \& Sonin, K. (2013). A political theory of populism. The Quarterly Journal of Economics, 128(2), 771-805. https://doi.org/10.1093/qje/qjs077

Acemoglu, D., Egorov, G., \& Sonin, K. (2015). Political economy in a changing world. Journal of Political Economy, 123(5), 1038-1086. https://doi.org/10.1086/682679

Acemoglu, D., Hassan, T. A., \& Robinson, J. A. (2010). Social structure and development: A legacy of the holocaust in Russia (Working Paper No. 16083). National Bureau of Economic Research. https://doi.org/10.3386/w16083

Acemoglu, D., \& Johnson, S. (2003). Unbundling institutions (Working Paper No. 9934). National Bureau of Economic Research. https://doi.org/10.3386/w9934

Acemoglu, D., Johnson, S., \& Robinson, J. (2002). The Rise of Europe: Atlantic Trade, Institutional Change and Economic Growth (Working Paper No. 9378). National Bureau of Economic Research. https://doi.org/10.3386/w9378

Acemoglu, D., Johnson, S., \& Robinson, J. (2004). Institutions as the Fundamental Cause of Long-Run Growth (Working Paper No. 10481). National Bureau of Economic Research. https://doi.org/10.3386/w10481

Acemoglu, D., Johnson, S., \& Robinson, J. A. (2001). Reversal of fortune: Geography and institutions in the making of the modern world income distribution (Working Paper No. 8460). National Bureau of Economic Research. https://doi.org/10.3386/w8460

Acemoglu, D., Naidu, S., Restrepo, P., \& Robinson, J. A. (2019). Democracy does cause growth. Journal of Political Economy, 127(1), 47-100. https://doi.org/10.1086/700936

Acemoglu, D., \& Robinson, J. A. (2001). A theory of political transitions. American Economic Review, 91(4), 938-963. https://doi.org/10.1257/aer.91.4.938 
Acemoglu, D., \& Robinson, J. A. (2012). Why nations fail: The origins of power, prosperity, and poverty. London, UK: Profile Books. https://doi.org/10.1355/ae29-2j

Acemoglu, D., \& Robinson, J. A. (2013). Economics versus politics: Pitfalls of policy advice (Working Paper No. 18921). National Bureau of Economic Research. https://doi.org/10.3386/w18921

Acemoglu, D., Robinson, J. A., \& Verdier, T. (2012). Can't we all be more like Scandinavians? Asymmetric growth and institutions in an interdependent world (Working Paper No. 18441). National Bureau of Economic Research. https://doi.org/10.3386/w18441

Andreou, A., Andrikopoulos, A., \& Nastopoulos, C. (2017). Chapter 1 - Debt markets, financial crises, and public finance in the Eurozone: Action, structure, and experience in Greece. In F. Economou, K. Gavriilidis, G. N. Gregoriou, \& V. Kallinterakis (Eds.), Handbook of Investors' Behavior During Financial Crises (pp. 3-28). London, UK: Academic Press. https://doi.org/10.1016/B978-0-12-811252-6.00001-3

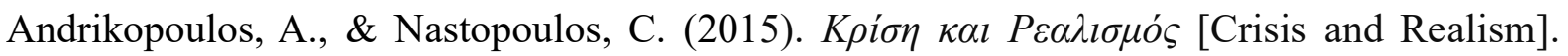
Athens: Propobos Publications.

Bitzenis, A., Vlachos, V., \& Schneider, F. (2016). An exploration of the Greek shadow economy: Can its transfer into the official economy provide economic relief amid the crisis? Journal of Economic Issues, 50(1), 165-196. https://doi.org/10.1080/00213624.2016.1147918

Bodenstein, T., Faust, J., \& Furness, M. (2017). European Union development policy: Collective action in times of global transformation and domestic crisis. Development Policy Review, 35(4), 441-453. https://doi.org/10.1111/dpr.12189

Chatzinikolaou, D., \& Vlados, C. (2019). Evolutionary economics and the Stra.Tech.Man approach of the firm into globalization dynamics. Business, Management and Economics Research, 5(10), 146-160. https://doi.org/10.32861/bmer.510.146.160

Christodoulakis, N. (2010). Crisis, threats and ways out for the Greek economy. Cyprus Economic Policy Review, 4(1), 89-96.

Christopoulou, R., \& Monastiriotis, V. (2016). Public-private wage duality during the Greek crisis. Oxford Economic Papers, 68(1), 174-196. https://doi.org/10.1093/oep/gpv054

European Commission. (2019). Country Report Greece 2019: Including an In-Depth Review on the prevention and correction of macroeconomic imbalances (2019 European Semester: Assessment of Progress on Structural Reforms, Prevention and Correction of Macroeconomic Imbalances, and Results of in-Depth Reviews under Regulation (EU) No 1176/2011) [Commission staff working document]. European Commission.

Glynos, J., \& Voutyras, S. (2016). Ideology as blocked mourning: Greek national identity in times of economic crisis and austerity. Journal of Political Ideologies, 21(3), 201-224. https://doi.org/10.1080/13569317.2016.1207300

Hardouvelis, G. A., \& Gkionis, I. (2016). A decade long economic crisis: Cyprus versus Greece. 
Cyprus Economic Policy Review, 10(2), 3-40.

Hodgson, G., \& Lamberg, J.-A. (2018). The past and future of evolutionary economics: Some reflections based on new bibliometric evidence. Evolutionary and Institutional Economics Review, 15(1), 167-187. https://doi.org/10.1007/s40844-016-0044-3

Ioannides, Y. M., \& Pissarides, C. A. (2015). Is the Greek crisis one of supply or demand? Brookings Papers on Economic Activity, 2015(2), 349-373. https://doi.org/10.1353/eca.2015.0004

Juko, S. (2010). Have the media made the Greek crisis worse? An inquiry into the credit crisis of the state. Economic Sociology_The European Electronic Newsletter, 12(1), 28-41.

Kazemi, H., \& Sohrabji, N. (2012). Contagion in Europe: Examining the PIIGS crisis. International Advances in Economic Research, 18(4), 455-456. https://doi.org/10.1007/s11294-012-9366-z

Kentikelenis, A. E. (2018). The social aftermath of economic disaster: Karl Polanyi, countermovements in action, and the Greek crisis. Socio-Economic Review, 16(1), 39-59. https://doi.org/10.1093/ser/mwx031

Koniordos, S. (2011). Living on borrowed money: On the social context and response of the current Greek crisis. Economic Sociology, 12(3), 48-57.

Kouretas, G., \& Vlamis, P. (2010). The Greek crisis: Causes and implications. Panoeconomicus, 57(4), 391-404. https://doi.org/10.2298/PAN1004391K

Koutsoukis, N.-S., \& Roukanas, S. (2011). The Greek crisis that should have been avoided. Scientific Bulletin - Economic Sciences, 10(1), 21-27.

Kuforiji, J. O. (2016). Greece financial crisis: The genesis, implications, and policy options. Journal of Applied Financial Research, 1, 55-74.

Leitch, D. (2019). Leaving like an Englishman: Assisting institutional reform in postcommunist Ukraine. Development Policy Review, 37(1), 111-128. https://doi.org/10.1111/dpr.12330

Magoulios, G., \& Chouliaras, V. (2014). The repercussions of the financial crisis (2008) on the foreign trade between Greece and the Balkan countries (BCs). In A. Karasavvoglou \& P. Polychronidou (Eds.), Economic Crisis in Europe and the Balkans (pp. 51-64). Heidelberg, Germany: Springer International Publishing. https://doi.org/10.1007/978-3319-00494-5_4

Mavroudeas, S. D. (2016). The Greek crisis: Structural or conjunctural? In T. Subasat, The Great Financial Meltdown (pp. 307-327). Cheltenham, UK: Edward Elgar Publishing. https://doi.org/10.4337/9781784716493.00028

Mitsakis, F. V. (2014). The impact of economic crisis in Greece: Key facts and an overview of the banking sector. Business and Economic Research, 4(1), 248-265. https://doi.org/10.5296/ber.v4i1.5515 
Mitsopoulos, M., \& Pelagidis, T. (2018). The lessons Quebec offers to Greece and Europe. Managerial and Decision Economics, 39(8), 846-853. https://doi.org/10.1002/mde.2967

Nelson, R., Dosi, G., Helfat, C., Winter, S., Pyka, A., Saviotti, P., Lee, K., Malerba, F., \& Dopfer, K. (2018). Modern evolutionary economics: An overview. Cambridge, UK: Cambridge University Press. https://doi.org/10.1017/9781108661928



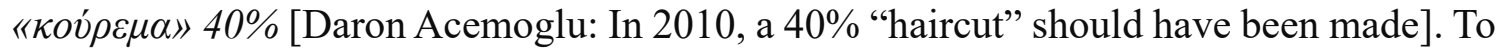
Vima Online. Retrieved from https://www.tovima.gr/2014/08/30/politics/ntaronatzemogloy-to-2010-eprepe-na-eixe-ginei-koyrema-40/

Pappas, T. S. (2013). Why Greece failed. Journal of Democracy, 24(2), 31-45. https://doi.org/10.1353/jod.2013.0035

Pelagidis, T., \& Mitsopoulos, M. (2016). Who's to blame for Greece? Cham, Switzerland: Palgrave Macmillan. https://doi.org/10.1057/9781137549204

Peneder, M. (2017). Competitiveness and industrial policy: From rationalities of failure towards the ability to evolve. Cambridge Journal of Economics, 41(3), 829-858. https://doi.org/10.1093/cje/bew025

Perroux, F. (1991). L'Économie du XXe Siècle [The Economy of the $20^{\text {th }}$ Century]. Paris, France: Presses Universitaires de France.

Pitelis, C. N. (2012). On PIIGs, GAFFs, and BRICs: An insider-outsider's perspective on structural and institutional foundations of the Greek crisis. Contributions to Political Economy, 31(1), 77-89. https://doi.org/10.1093/cpe/bzs002

Porter, M. (1990). The competitive advantage of nations. New York, US: Free Press. https://doi.org/10.1007/978-1-349-11336-1

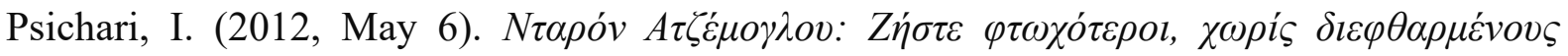


Retrieved from https://www.tovima.gr/2012/05/06/world/ntaron-atzemogloy-zisteftwxoteroi-xwris-dieftharmenoys-politikoys/

Raffaelli, R., \& Glynn, M. A. (2015). Institutional innovation: Novel, useful, and legitimate. In C. Shalley, M. A. Hitt, \& J. Zhou (Eds.), The Oxford Handbook of Creativity, Innovation, and Entrepreneurship. Oxford, UK: Oxford University Press.

Siskos, D., \& Marangos, J. (2017). Restructuring accounting education: The key to avoiding another financial crisis in Greece. In J. Marangos (Ed.), The Internal Impact and External Influence of the Greek Financial Crisis (pp. 207-234). Cham, Switzerland: Springer International Publishing. https://doi.org/10.1007/978-3-319-60201-1_12

Skalkos, D. P. (2018). Studying the political economy of reforms: The Greek case, 2010-2017. Theoretical and Applied Economics, XXV(2(615), Summer), 163-186.

Stockhammer, E. (2017). Post-Keynesian economics. In L. Fischer, J. Hasell, J. C. Proctor, D. 
Uwakwe, Z. Ward-Perkins, \& C. Watson (Eds.), Rethinking Economics: An Introduction to Pluralist Economics (pp. 6-18). Abingdon, Oxon; New York, NY: Routledge. https://doi.org/10.4324/9781315407265

Sumer, F. (2015). Political and institutional roots of the Greek debt crisis. Middle East Review of Public Administration, 1(1), 1-29.

Theocharis, Y., \& Deth, J. W. van. (2015). A modern tragedy? Institutional causes and democratic consequences of the Greek crisis. Representation, 51(1), 63-79. https://doi.org/10.1080/00344893.2015.1011464

Triantopoulos, C., \& Staikouras, C. (2017). SOEs in Greece: Structural reforms, economic crisis and financial constraints. International Journal of Public Policy, 13(6), 358. https://doi.org/10.1504/IJPP.2017.087884

Tsoulfidis, L., Alexiou, C., \& Tsaliki, P. (2016). The Greek economic crisis: Causes and alternative policies. Review of Political Economy, 28(3), 380-396. https://doi.org/10.1080/09538259.2016.1163819

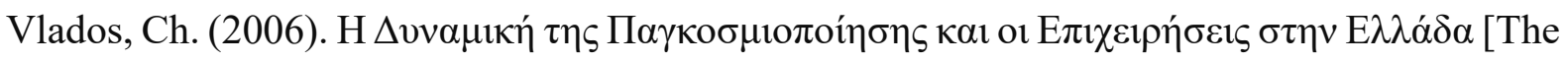
dynamics of globalization and the enterprises in Greece]. Athens: Kritiki Publications.

Vlados, Ch. (2019a). Porter's diamond approaches and the competitiveness web. International Journal of Business Administration, 10(5), 33-52. https://doi.org/10.5430/ijba.v10n5p33

Vlados, Ch. (2019b). Notes on the main analytical insufficiencies of the Marxist theoretical tradition for the comprehension of the contemporary global economy. Journal of Economic and Social Thought, 6(3), 132-155. https://doi.org/10.1453/jest.v6i3.1942

Vlados, Ch., \& Chatzinikolaou, D. (2019a). Business ecosystems policy in Stra.Tech.Man terms: The case of the Eastern Macedonia and Thrace region. Journal of Entrepreneurship, Management and Innovation, 15(3), 163-197. https://doi.org/10.7341/20191536

Vlados, Ch., \& Chatzinikolaou, D. (2019b). Crisis, institutional innovation and change management: Thoughts from the Greek case. Journal of Economics and Political Economy, 6(1), 58-77. https://doi.org/10.1453/jepe.v6i1.1854

Vlados, Ch., Deniozos, N., \& Chatzinikolaou, D. (2019). Global crisis and restructuring: Theory, analysis, and the case of Greece. KSP Books. https://doi.org/10.2139/ssrn.3433099

Vlados, Ch., Deniozos, N., Chatzinikolaou, D., \& Demertzis, M. (2018). Towards an evolutionary understanding of the current global socio-economic crisis and restructuring: From a conjunctural to a structural and evolutionary perspective. Research in World Economy, 9(1), 15-33. https://doi.org/10.5430/rwe.v9n1p15

Zettelmeyer, J., Trebesch, C., \& Gulati, M. (2013). The Greek debt restructuring: An autopsy. Economic Policy, 28(75), 513-563. https://doi.org/10.1111/1468-0327.12014 


\section{Copyright Disclaimer}

Copyright for this article is retained by the author(s), with first publication rights granted to the journal.

This is an open-access article distributed under the terms and conditions of the Creative Commons Attribution license (http://creativecommons.org/licenses/by/3.0/). 